\title{
The Development of TRAM Model for Blockchain Use Readiness Among MSMEs in Indonesia
}

\author{
Ayu Endah Wahyuni ${ }^{1 *}$, Anita Juraida ${ }^{1}$, Asep Anwar $^{1}$ \\ ${ }^{1}$ School of Industrial Engineering, Widyatama University, Bandung, 40125, Indonesia \\ "Corresponding author. Email: ayu.endah@widyatama.ac.id
}

\begin{abstract}
MSMEs have a sufficiently large role and become the strength of the Indonesian economy. However, MSMEs often experience obstacles in competitiveness, especially in facing global competition, including the access to capital, information and technology, organization and management, as well as to business networks and partnerships. The adoption of blockchain technology is one of the considerations to minimize the MSMEs' problems. This is because this technology can provide benefits for MSMEs, such as increasing cost efficiency, increasing profit and minimizing the role of intermediaries, as well as increasing the competitiveness. This study aims to measure and analyze the readiness of MSMEs in using blockchain technology, before this technology is applied in Indonesia in the MSME sector. Investigations to see the readiness of MSMEs in using blockchain technology with the TRAM model approach is developed by adding a variable, that is perceived risk. This model is an integration of the Technology Readiness Index (TRI) and Technology Acceptance Model (TAM), as well as the addition of variables of perceived risk and intention-to-recommend in this study. Data processing will use the Partial Least Square Path Modeling (PLS-PM) method. The results of this study will show the influence of the variables in this research model.
\end{abstract}

Keywords: blockchain technology, MSME, TRAM, TRI

\section{INTRODUCTION}

The role of MSMEs is very large in a country's economic growth. MSMEs has the potential to contribute quite a lot. This is because MSMEs in Indonesia provide benefits of around $60 \%$ of GDP [1]. In addition, this is supported by MSME growth data from 2017 to 2018, showing an increase of around 2\% [2]. Meanwhile, the SME sector can become the strength of the national economy that can build the economy in Indonesia. The number of business units in MSMEs currently reaches $99 \%$ of the total business units in Indonesia. Type of micro business is the majority scale with 63 million business units in motion, followed by small businesses with 783,000 business units in Indonesia [3].

The government has set a target for the contribution of MSMEs to the Indonesian economy of around $18 \%$ of exports and $61 \%$ of GDP in 2020 , and $30.2 \%$ of exports and $65 \%$ of GDP in 2024 [4]. The target set by the government is a challenge for business actors to develop and improve their business.

In the current digital era, MSMEs in Indonesia are required to be competitive. However, there are many obstacles that must be faced by business actors, including: limited capital, distribution, financial inefficiency, lack of innovation, and limited technological knowledge, as well as not having business license [5]. One of the significant obstacles experienced by MSMEs in Indonesia is the limited knowledge of technology and innovation. This limitation has a considerable impact on MSMEs in the current COVID
19 pandemic situations. Most MSMEs that survive and develop in the current situation have the knowledge of digital technology and are connected to the marketplace. However, the number is only about $13 \%$ of the total MSMEs in Indonesia. The small number of MSMEs that can survive are able to adapt to the current situations through product innovation, technology mastery, and the capability to meet the demand [4].

In the COVID 19 pandemic situations, understanding the technology for business actors is highly expected for the online marketing process. Some MSMEs that master digital technology also experience several obstacles, namely limited internet access, insecurity of digital transactions, and inadequate technological infrastructure [6].

If most MMSMEs in Indonesia can understand and master the digital technology today, there will be many benefits that will be received by business actors, such as: up-to-date information, efficiency in marketing costs, and operational effectiveness [7]. In addition, technological knowledge for business actors can increase economic growth. However, mastering of technology alone is not enough for MSMEs to be competitive. However, increasing the quality of human resources, acquiring customers, and innovating are the challenges for MSMEs in Indonesia through the effective understanding and mastery of technology [8].

One technology that is relatively new and has not been applied to MSMEs in Indonesia is the technology with a blockchain system. This blockchain technology can answer the problems experienced by MSMEs in Indonesia. This technology can provide benefits for MSMEs, including: 
increasing cost efficiency, increasing profits and minimizing the role of intermediaries, as well as increasing the competitiveness [9]. In addition, the blockchain technology can advance businesses and companies more. This is due to the usefulness of this technology in the efficiency of transaction verification, transaction data recording, business activities, transaction processing and documentation [10]. The presence of blockchain technology can create new opportunities for businesses among MSMEs in Indonesia by creating jobs and providing benefits. The advantages provided by blockchain technology include: transaction security, eco-friendliness, cost efficiency and competitiveness [11].

Thus, this study aims to test and predict the readiness of MSMEs in Indonesia in using blockchain technology by taking into account the risk perceptions of business actors through the development of research model. Respondents who are planned as the unit of analysis for this research are MMSMEs in Indonesia. Then, the variables involved in this research model include: TRI, perceived risk, perceived usefulness, perceived ease-of-use, intention to use, and intention to recommend.

\section{LITERATURE REVIEW}

\subsection{Blockchain Technology}

Blockchain was introduced by Satoshi Nakamoto who discussed about bitcoin. The blockchain system refers to a peer-to-peer (P2P) electronic cash system of bitcoin or electronic payments with cryptography. This makes both parties can conduct the transaction process directly without the involvement of third party [12].

Blockchain technology has an impact on the international business area. This affects the corporate governance to be better. The existence of this technology can improve business and transaction cost efficiency, as well as data security systems [13].

Some of the characteristics of blockchain technology are transactions carried out in P2P (peer-to-peer), easy to build and connect, cost efficiency, easy access to transaction data, efficient regulation costs, integrity, minimum transaction failure. However, there is something that needs to be considered in this technology, which is difficult to determine the person-in-charge if a problem occurs, the limited number of payment transactions, transactions are too easy-to-trace, and there is no solution when there is tapping, as well as the limitation in handling large transactions [14].

Blockchain technology turns out to provide benefits for business people such as MSMEs when adopting this technology [15], which are cost efficiency, overcoming resource constraints, offering high speed in transactions, maintaining product originality, facilitating the tracking of purchases of goods, and preventing fraud in business.

\subsection{TRAM (Technology Readiness Index \& Theory Acceptance Model)}

TRAM is an integration between TRI and TAM, whereas TR shows the influence of the adoption of new technology by individuals [16], while TAM predicts the users' acceptance of new technology [17]. The existence of TRAM is a TAM model development that is extended along with additional variables to strengthen the explanation and prediction of technology acceptance behavior by individuals [17]. The individual experience and knowledge about general technology affects the perception and behavior of individual acceptance of new technology [16]. It can be said that TR shows individual perceptions of general technology and TAM relates the individual's perceptions to the presence of certain technologies [16]. In addition, TRAM has been used to identify users' acceptance of certain technologies in various industries [16].

\subsection{Theoretical Framework and Hypothesis Development (If Applicable)}

This study develops an existing research model. The main model of this research comes from the model [16] which is then developed by adding several research variables. The research model [16], initially integrated the concepts of TRI and TAM. Then, this study adds the variables of perceived risk and intention-to-recommend. The perceived risk of variability comes from the research model [23] and the intention-to-recommend comes from the study by [24].

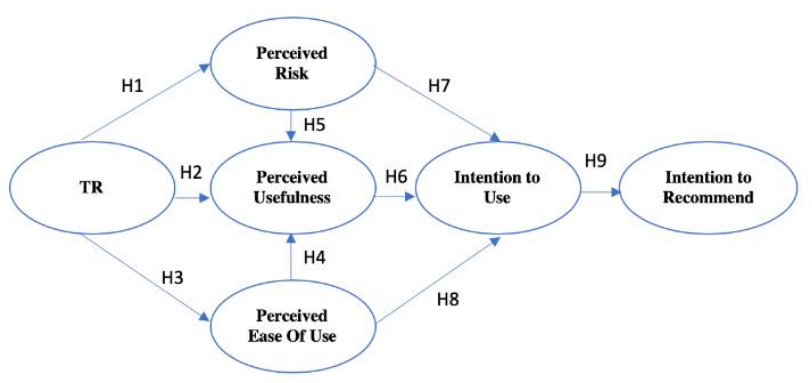

Figure 1 Theoretical Framework

In this study, the addition of perceived risk variable is needed to determine the risk faced by individuals in using technology and is a major factor for consumer resilience in various technologies, especially those involving financial 
transactions [18]. This is because the use of internet by individuals carries a certain risk in terms of transactions, without meeting in person [19].

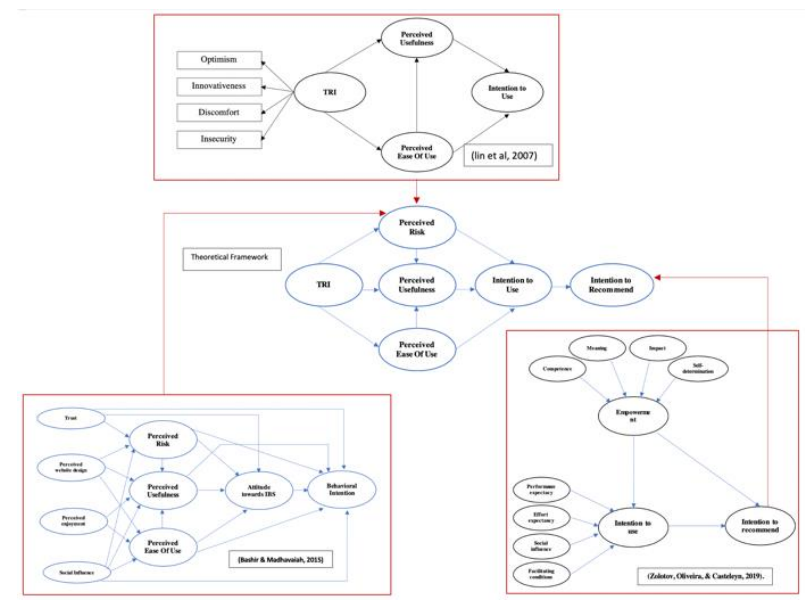

Figure 2 Research Model Development Scheme

The intention-to-recommend variable is one of the factors used in the development of this research model. Recommendation positively affects the behavior and attitudes of other customers who are likely to adopt the technology [20]. However, this factor has not been studied much, because most of the previous studies only focused on the construction of technology-usage behavior. This study uses six variables, including the technology readiness index (TRI), perceived risk, perceived usefulness, perceived easeof-use, intention-to-use, and intention-to-recommend.

\subsection{Hypothesis Development}

Risk is one of the important aspects in individual resilience when adopting technology that involves financial transactions [18]. This study will examine the effect of TRI as a factor in accepting new technology on perceived risk in technological devices.

$\mathbf{H}_{1}$ : TR has a positive influence on the perceived risk of blockchain technology.

Technology Readiness Index (TRI) is known to be the main factor in the acceptance and use of new technology [16]. The Technology Readiness Index (TRI) in the optimism and innovative dimensions has a positive effect on the use of technological devices [25]. Meanwhile, the relationship between the TRI and the cognitive dimensions of TAM (PU and PEOU) has been explored and obtained. Thus, the TRI has a positive influence on PU and PEOU [26]. The existence of a combination of TAM and TR models aims to evaluate the use of technological devices by individuals [16]. Therefore, this study will examine the hypotheses on blockchain technology.

$\mathbf{H}_{2}$ : TR has a positive influence on the perceived usefulness of blockchain technology.
H3: TR has a positive influence on the perceived easeof-use of blockchain technology.

Perceived risk is part of the TAM construction to increase the predictability of behavior. In previous studies, perceived risk has a negative effect on attitudes and behavioral intentions of individuals in adopting certain technologies [27].

H5: Perceived risk has a positive influence on the perceived ease-of-use of blockchain technology.

Perceived risk can be a determinant of technology-adoption behavior. When the level of risk in the technology used is high, the usefulness and ease-of-use of technological devices are less experienced by individuals [28].

H7: Perceived risk has a positive influence on the intention-to-use of blockchain technology.

The PEOU and PU variables show consistent individual behavioral intentions in the use of technology. If individuals find it easy to use PU of technology, they will accept this technology [29]. If individuals feel the ease in using technology, then there will be a belief that the technology has benefits and goals [30]. "The easier a technology is to use, the more useful it is".

$\mathbf{H}_{4}$ : $\quad$ Perceived ease-of-use has a positive influence on the perceived usefulness of blockchain technology.

H6: Perceived usefulness has a positive influence on the intention-to-use of blockchain technology.

Hs: Perceived ease-of-use has a positive influence on the intention-to-use of blockchain technology.

Recommendations can be said to be a post-adoption behavior that recommends the key to success of a technology [31]. Technology-related recommendations have not been studied much. Individuals who have high 
intentions to use the technology, tend to recommend it to others [32].
H9: The intention-to-use has a positive influence on the intention-to-recommend of blockchain technology.

Table 1 Source of Research Variables

\begin{tabular}{|c|l|l|}
\hline Num & \multicolumn{1}{|c|}{ Variable } & \multicolumn{1}{c|}{ Resource } \\
\hline 1 & TR (Technology Readiness) & {$[21]$} \\
\hline 2 & Perceived Risk & \multirow{2}{*}{ [22] [16] [17] [23] } \\
\hline 3 & Perceived Usefulness & \\
\hline 4 & Perceived Ease-of-Use & \\
\hline 5 & Intention-to -Use & {$[24]$} \\
\hline 6 & Intention-to-Recommend & \\
\hline
\end{tabular}

\section{RESEARCH METHODOLOGY}

This research methodology begins with determining the topic of this research consisting of several stages, including: preliminary literature study, observation of data and information, determination of problem formulation and research objectives, and problem boundaries. The output at this stage is regarding the Acceptance of Blockchain Technology among MSMEs in Indonesia.

The development of the research model is carried out in several stages including: the preparation of the elements of the research model, the operationalization of variables and the preparation of statement items, and the preparation of research hypotheses. This stage generates 9 (nine) research hypotheses. After that, the determination of data collection techniques will be done followed by the determination of sampling techniques and design of research instruments.

This study uses a survey questionnaire instrument with MSMEs as the unit of analysis. The questionnaire consists of three main parts. Regarding the demographic information data of respondents, questions that have been arranged are based on the operationalization of variables. Data processing will use the partial least square path modeling (PLS-PM) method with the amount of data to be collected as many as 100 MSMEs respondents.

\section{DISCUSSION}

The application of blockchain technology in technological devices has a beneficial function in transactions, especially by business actors. However, this technology is not yet fully applicable in Indonesia. One of the obstacles is limited infrastructure and regulations, as well as the ability of the community to implement them. Moreover, the number of researches that discuss the acceptance of blockchain technology is still very limited. Thus, the literature obtained to support this research is not optimal. Therefore, this study attempts to determine the readiness of MSMEs actors to accept and use blockchain technology through technological devices in conducting transactions.

\section{CONCLUSION}

This research is expected to show the readiness of MSMEs in Indonesia in facing new technologies. One of the technologies that is still new and has not been fully implemented in Indonesia is the blockchain technology. This technology is known to have many advantages including: cost efficiency, overcoming resource constraints, offering high speed of transactions, maintaining product originality, facilitating the tracking of purchase of goods, and preventing fraud in business. This technology can help MSMEs in dealing with business problems, which can hinder their competitiveness. However, there are not many researches on the relationship between blockchain technology and MSMEs. Therefore, this study seeks to measure and investigate the readiness of MSMEs in Indonesia in accepting the blockchain technology, so that this technology deserves to be recommended.

\section{ACKNOWLEDGMENTS}

The authors gratefully acknowledge the support of the Indonesia Ministry of Research and Technology / National Research and Innovation Agency for the Year 2020, The Lecturer Research Grant for Beginner (PDP), with the Contract Number: 002 / SP4 / LP2M-UTAMA / VI / 2020.

\section{REFERENCES}

[1] J. Widodo, "UMKM Mampu Dorong Pertumbuhan Ekonomi," september 2019. [Online]. Available: http://pelakubisnis.com/2019/09/umkm-mampudorong-pertumbuhan-ekonomi/.

[2] K. K. D. UKM, "Data UKM," 2018. [Online]. Available: http://www.depkop.go.id/data-umkm.

[3] K. Perekonomian, "Stimulus untuk UMKM," March 2020. [Online]. Available:

https://indonesia.go.id/narasi/indonesia-dalamangka/ekonomi/stimulus-untuk-umkm.

[4] Menkop, "Ini Target Kontribusi UMKM Terhadap Ekonomi di 2020-2024," 0708 2020. [Online]. Available: https://www.idxchannel.com/market- 
news/ini-target-kontribusi-umkm-terhadap-ekonomi-di2020-2024.

[5] A. Permana, "Inilah 8 Permasalahan UMKM Yang Sering Terjadi," 0301 2020. [Online]. Available: https://seoanaksholeh.com/bisnis/permasalahan-umkm.

[6] E. Satriya, "Tak Hanya Gagap Teknologi, UMKM Sulit Go Online karena Kendala Berikut," 21072020. [Online]. Available: https://www.jawapos.com/ekonomi /bisnis/21/07/2020/tak-hanya-gagap-teknologi-umkmsulit-go-online-karena-kendala-berikut/.

[7] D. Nugraha, "Efek Perkembangan Teknologi Bagi Kemajuan UMKM," 2711 2019. [Online]. Available: https://www.paper.id/blog/tips-dan-nasihat-umkm/ manfaat-perkembangan-teknologi-bagi-umkm/.

[8] A. Yuanda, "Begini cara teknologi bantu UMKM berkembang," 0612 2019. [Online]. Available: https://www.indotelko.com/read/1575528431/carateknologi-umkm.

[9] Merlina, "Ingin Terapkan Blockchain di Bisnis Anda? Baca Ini Dulu," 1707 2019. [Online]. Available: https:// blockchainmedia.id/ingin-terapkan-blockchaindi-bisnis-anda-baca-ini-dulu/.

[10] L. Nugroho, "Tak Hanya untuk Bitcoin, Blockchain Juga Bisa Dimanfaatkan untuk Bisnis", 06 03 2018. [Online]. Available:

https://ekonomi.kompas.com/read/ 2018/03/06/ 170800426/tak-hanya-untuk-bitcoin-blockchain-jugabisa-dimanfaatkan-untuk-bisnis.

[11] Oscar, "Penerapan Blockchain Dinilai akan Munculkan Peluang Bagi Pelaku Usaha," 04082020. [Online]. Available: https://www.merdeka.com/uang/ penerapan-blockchain-dinilai-akan-munculkanpeluang-bagi-pelaku-usaha.html.

[12] S. Nakamoto, "Bitcoin: a peer-to-peer electronic cash system," 2008. [Online]. Available: https:// bitcoin.org/ bitcoin.pdf.

[13] A. Hooper and D. Holtbrügge, "Blockchain technology in international business: changing the agenda for global governance," Review of International Business and Strategy, pp. 183-200, 2020.

[14] F. S. Commission, A Study on Introduction of Blockchain Technology in the Financial Sector, 2016.

[15] N. Gupta, "Should small and medium-sized enterprises adopt blockchain?," 1911 2019. [Online]. Available: https://medium.com/akeo-tech/should-small- and-medium-sized-enterprises-adopt-blockchainff6c1cca784f.

[16] C. S. H. a. S. P. Lin, "Integrating technology readiness into technology acceptance : the TRAM model," Psychology \& Marketing, pp.641-657, 2007.

[17] D. a. H. D. McFarland, "Adding contextual specificity to the technology acceptance model," Computers in Human Behaviour, pp.427-447, 2006.

[18] B. S. A. a. I. M. Vatanasombut, "How to retain online consumers," Communications of the ACM, pp. 65-69., 2004.

[19] M. a. P. P. Featherman, "Predicting e-services adoption: a perceived risk facets perspective," International Journal of Human-Computer Studies, pp. 451-474, 2003.

[20] Y. L. H. K. V. G. J. H. S. a. H. F. Liu, "An empirical investigation of mobile government adoption in rural China: a case study in Zhejiang province," Government Information Quarterly, pp. 432-442, 2014.

[21] A. Parasuraman, "Technology Readiness Index (TRI) a multiple-item scale to measure readiness to wmbrace new technologies," Journal of Service Research, pp.307-320, 2000.

[22] F. Davis, "Perceived usefulness perceived ease of use, and user acceptance of information technology," MIS Quartely, pp. 319-340, 1989.

[23] I. Bashir and C. Madhavaiah, "Consumer attitude and behavioural intention towards Internet banking adoption in India," Journal of Indian Business Research, pp. 67-102, 2015.

[24] M. N. Zolotov, T. Oliveira and S. Casteleyn, "Citizens' intention to use and recommend eparticipation Drawing upon UTAUT and citizen empowerment," Information Technology \& People, pp. 364-386, 2019

[25] V. G. F. G. J. a. V. R. A. Liljander, "Technology readiness and the evaluation and adoption of selfservice technologies," Journal of Retailing and Consumer Services, Vol. 13 No. 3, pp. 177-191, 2006

[26] R. L. J. a. S. S. Walczuch, "The effect of service employees' technology readiness on technology acceptance," Information \& Management, Vol. 44 No. 2, pp. 206-215., 2007. 
[27] T. L. D. a. Y. A. Cheng, "Adoption of Internet banking: an empirical study in Hong Kong," Decision Support Systems, Vol. 42 , No. 3, pp. 1558-1572, 2006.

[28] P. Pavlou A, "Consumer Acceptance of Electronic Commerce: Integrating Trust and Risk with the Technology Acceptance Model," International Journal of Electronic Commerce, Vol.7, No.3, pp. 69-103, 2003.

[29] A. C. N. a. E. M. Lunney, "Wearable fitness technology: a structural investigation into acceptance and perceived fitness outcomes," Computers in Human Behavior, Vol. 65, pp. 114-120, 2016.

[30] V. a. M. M. Venkatesh, "Why don't men ever stop to ask for directions? Gender, social influence, and their role in technology acceptance and usage behavior," MIS Quarterly, Vol. 24 No. 1, pp. 115-139, 2000.

[31] M. C. S. a. B. T. Luo, "Post-adoption behavior of digital media: the merge of $U \& G$ theory and affect event theory," Pacific Asia Conference on Information Systems (PACIS)Chia-Yi, Taiwan, 2016.

[32] T. T. M. B. G. a. C. F. Oliveira, "Mobile payment: understanding the determinants of customer adoption and intention to recommend the technology,"

Computers in Human Behavior, Vol. 61, pp. 404-414, 2016. 